\title{
Paideusis
}

\section{A Response to Jackson}

\section{Kieran Egan}

Volume 7, Number 2, 1994

URI: https://id.erudit.org/iderudit/1073281ar

DOI: https://doi.org/10.7202/1073281ar

See table of contents

Publisher(s)

Canadian Philosophy of Education Society

ISSN

0838-4517 (print)

1916-0348 (digital)

Explore this journal

Cite this document

Egan, K. (1994). A Response to Jackson. Paideusis, 7(2), 45-47.

https://doi.org/10.7202/1073281ar

This document is protected by copyright law. Use of the services of Erudit (including reproduction) is subject to its terms and conditions, which can be viewed online.

https://apropos.erudit.org/en/users/policy-on-use/ 


\section{A Response to Jackson}

Kieran Egan writes:

I am grateful for the invitation to respond to Michael Jackson's review of Romantic Understanding. It is a careful and generous look at the overall project of which this book is a part. Perhaps, it would be best if I address only what seems the central criticism. This is that the recapitulation thesis on which it was precariously constructed has, unseen by me, collapsed; the historical parallels are, perhaps, interesting, but the causal role required by a recapitulation thesis simply cannot be sustained.

Let me try to restate the recapitulation argument briefly, shorn of the curriculum and teaching implications, and indicate, as might be expected, that I think the difficulties may be in part due to Jackson's misreading-for which, alas, I must no doubt bear most of the blame. I argue that certain "technologies"-I can't think of a better term, though recognize its inadequacies-that have been developed in cultural history influence the kind of sense we can make of the world and of experience. As children individually recapitulate the development of these "technologies," they also acquire along with them particular distinctive ways of making sense of the world and of experience. What "technologies"? Things like language and literacy, for example. Becoming an oral language-user has certain implications for how one can make sense of, or understand, the world-whether one lived long ago or today. So we find that most language-users' thinking shares certain features such as generation of mental images of what is possible rather than only of what is actual, shaping experience into story-structures that makes it both memorable and affectively engaging, exploitation of the metaphoric potential of all languages, and so on.

"Literacy" is a short-hand term, not just for coding and decoding skills, but for a complex of cognitive capacities that can be sustained by literacy but which are rarer and less readily. sustained by the conditions of oral cultures. (This is a contentious area, a hunting ground of the ideologue-raptors of the academic jungle, so I need to emphasize that I do not hold the beliefs in a kind of evolutionary scheme in which "literacy" is clearly progress beyond "orality.") "Literacy" encourages a sense of a distinct "reality," access to which becomes problematic, but exploration of which begins with its more dramatic features-with the limits of reality and the extremes of human experience; the threats of an autonomous reality encourage early literates to form associations with those things that seem best able to overcome the threats of everyday reality-heroes, defensive imaginary "twins," transcendent virtue, like compassion, power, tenacity, and so on, embodied in institutions, football teams, relationships, and so on. These are among the characteristics commonly identified with a romantic perception of the world and of experience. We find them commonly in our cultural history, particularly in periods and times of a relatively unsophisticated literacy, and in adolescent students today.

Further, "technologies" include the kinds of communities or institutions that support sustained theoretic thinking, and also the kind of very complex self-reflexiveness that supports sophisticated irony. But let us stick with language and literacy for now. Some of the vagueness Jackson finds may be due to his looking for more sharply etched distinctions among these kinds of under- 
standing, or sense-making, than they seem to me to permit. But let me leave that aside, too, and address the causal claim.

The causal claim is not that the historical development of a kind of understanding somehow influences the students' development of the same kind of understanding. Such claims were common in the nineteenth century; as Herbert Spencer puts it:

If there be an order in which the human race has mastered its various kinds of knowledge, there will arise in every child an aptitude to acquire these kinds of knowledge in the same order .... Education should be a repetition of civilization in little. (Spencer, 1861, 76).

The problem for such recapitulation theories was to locate why there "will arise in every child" the aptitude to master knowledge in the order it was invented or discovered. How could one construct a curriculum based on such a principle? Teach a Ptolomaic before a Copernican view of the universe? None of the recapitulation schemes succeeded in persuasively identifying just what was recapitulated, and so they died out.

What I try to show is that in certain social and cognitive conditions accumulating such "technologies" as language and "literacy," and theoretic thinking and irony causes certain kinds of understanding. What I have been trying to spell out in Primary Understanding and Romantic Understanding are what some of these "certain conditions" are, and what a couple of "certain kinds of understanding" are like. The causal claim, then, is not that $b$ (cultural development) causes $c$ (children's educational development) but rather that $a$ ("technologies" that support particular kinds of understanding) cause $b$ and $c$. The parallels between $b$ and $c$, that is to say, are due to their both being the result of certain developments that influence the way minds make sense of their world and experience. A basic assumption is that human minds everywhere are pretty much the same-the source of the kinds of differences we may identify in people's thinking are due to the "technologies" they acquire.

I am trying to show that reconceiving education as the recapitulation of kinds of understanding can give us quite precise and practical help in the daily business of educating children. Some of the practical implications are explored further (Egan, 1986 and 1992).

Jackson has evidently read more of my work than I have, and he has certainly identified a number of inconsistencies-some relatively minor, to be fixed by more careful writing, and others more major. I would like to think the latter were due in part to my getting an increasingly clear bandle on this scheme, which I confess remains a bit opaque to me. I do obviously think there is something in it beyond some surprising parallels between cultural history and features of students' thinking today. I feel as though I cannot get off the roundabout, and keep trying to write something that will clear up the confusions generated by the previous book. So, I am currently working on a book that steps back from the series I have been flogging my way through and lays out the recapitulation thesis in some detail, arguing also that from such an unlikely source can come some practical solutions to a number of the impasses schooling faces today. 


\section{References}

Kieran Egan. Teaching as Story Telling. London, Ontario: Althouse Press, 1986; Chicago: University of Chicago Press, 1989; London: Routledge, 1989.

Kieran Egan. Imagination in Teaching and Learning. London, Ontario: Althouse Press, 1992; Chicago: University of Chicago Press, 1992; London: Routledge, 1992.

Herbert Spencer. Education: Intellectual, Moral and Physical. London: G. Manwasing, 1861. 